\title{
Governing race in Australia: historical and contemporary perspectives
}

\author{
David McCallum
}

\begin{abstract}
-
This paper seeks to outline the ways in which in Australia, as with similarly colonized territories in the nineteenth century, rulers sought to shape conduct among racialized parts of the population by seeking to governmentalize the category of race, producing and managing 'mixed race' groups with specific effects for their communities, their children and descendants. These concerns, which implicate the relations between the social sciences and government, continue to be relevant to modern Australian forms of governing.

Against a broader decline of sovereign government and its replacement with liberal governing, sovereign power to 'take life or let live' was replaced by a power to 'give life or let die' (Foucault, 2004:247). This is a power quite separate from a disciplinary power centred on individual bodies. Bio-politics is regulatory, centred not on the body but on life itself, bringing together mass effects characteristic of a population; it is a technology which tries to control random events and protect the security of the whole from internal dangers. In this technology bodies are replaced by general biological processes. Power would no longer take from the populace; rather, population itself would become an object of government. It is this shift to bio-political power that laid the grounds for an intense interest in the government of defined groups, using race as a population category.
\end{abstract}

Keywords-Race, Australia, government, history of human sciences

Authors Name/s per Professor David McCallum, Emeritus Professor,

Victoria University

Melbourne Australia

About Author (s):

\begin{tabular}{|c|c|}
\hline Image & $\begin{array}{c}\text { Emeritus Professor David McCallum is at } \\
\text { the Centre of International Research on } \\
\text { Education Systems at Victoria University, } \\
\text { Melbourne. }\end{array}$ \\
\hline
\end{tabular}

